\title{
Senior Management Incentive and Corporate's Value
}

\author{
Xueqin Jiang \\ School of economics \\ Yangtze University \\ Jingzhou, Hubei, China \\ jxueqinjpu@hotmail.com
}

\author{
Ian Liu \\ FIREL College of Business Administration \\ University of North Texas \\ Denton, TX, USA \\ ian.liu@unt.edu
}

\begin{abstract}
It has been the focus of attention for all parties that how to encourage enterprises senior managerial personnel. As the important measurement of the corporate value, Tobin-q provides important guidance for management compensation. Based on the data of the public listed companies in China, This paper investigates company values and the relationship between the Tobin-q value and senior management's salary incentive. We find that the annual incomes of senior are highly related with Tobin-q value and q-value elasticity of the salary level increases if q-value decreases.
\end{abstract} Tobin-q

Keywords- corporate governance structure; salary incentive;

\section{INTRODUCTION}

After the financial crisis and the European debt crisis, many firms began to cut the salaries of management. "GuotaiJunan" remuneration event of 2009 and "Nokia" payment event of 2013, made the society increasingly aware on the company executive compensation practice. Senior management mainly refers to the chief executive officer (CEO), the general manager or president, and is the product by separating the ownership and management of a company. Based on the principal-agent theory, the design of CEO's compensation plays an extremely important role in the company's development process, by stimulating their enthusiasm and talent under the necessary constraints and aligning their interest with shareholders.

\section{LITERATURE REVIEW}

According to principal-agent theory, one solution about the agency problem is to implement performance-based payment system. As CEO's payment is decided by the company board, more and more researches combined CEO's compensation with corporate governance structures, linked together with the value of the company to analyze the impact for CEO's payment by the composition of the board, the internal and external equity structure, and the company value.

\section{A. Corporate Governance Model}

Under the different economic and cultural environment, the governance model is different. Nickell (1995) defined two main models: The one model was based on well-developed stock market, and each company shares were controlled by shareholders including the company's institutional or individual investors, represented by UK and USA. The second type was represented by Japan and Germany, and under this model, the shares of the company were controlled by the shareholders who were the long-term stakeholders with the company. With the previous governance model, CEO had greater power on controlling over the company, while dispersed ownership structure weakened the shareholders powers. At the same time, the stock market with high fluidity and developed professional manager market could constraint the market decision of CEOs, and force them to do their best to improve corporate performance. With the second governance model, the board might be controlled by insiders, and the CEO might be influenced by various stakeholders, so this might weaken the relationship between the CEO compensation and firm performance.

\section{B. Board Structure}

The board is a main internal control mechanism to coordinate the interests of shareholders and top managers. One responsibility of the board is to monitor the CEO's performance and to determine their remuneration levels accordingly. Based on economic assumptions, in order to maximize his personal emoluments, CEOs need to avoid these control mechanisms, and try to dominate or control board (Eisenhardt, 1989). Walsh and Seward (1990) pointed out that CEO could only seek safety by influencing the work of the board. Westphal and Zajac (1995) considered that the board should not only restrict the CEO's total compensation, the also improve variable compensation.

\section{Operating Performance and Corporate Value}

According to agency theory, because of information asymmetry, shareholders would like to sign a reward performance contract with managers to reduce the agency costs, in order to maximize their wealth. In these contracts, the company's manager compensation will be determined by the company's operating performance. Thus, as a self-interested company manager, he will seek to improve his reward by improving the company's operating performance. Meanwhile, corporate managers are risk avoidant, and shareholders are risk neutral. If the manager has no residual claim on the company, he will avoid higher-yielding projects with higher risk and choose less risk projects with low income. If a manager has a residual claim, he will invest in higher-yielding projects, so that his welfare will be improved. Therefore, when the company's senior management holds shares of the company, just like wearing a "golden handcuffs ", his personal interests will be closely tied together with the company's interests. Therefore, we can assume that there is a significant positive correlation between the companies' operating performance and the senior management stake. 


\section{Tobin- $q$ and Corporate Value}

Tobin's q was proposed by Tobin (1969). It was developed by Abel (1979), Yosbikawa (1980) and Hayashi (1982), and became the mainstream investment theory from 1970s to 1980s. Tobin (1969) considered that the basic factor influencing the investment decisions was the ratio of the company's market value and replacement cost of capital stock, and the ratio was defined as q-value, later called Tobin-q, or Tobin's marginal q. As q-value summarized all future information about the decisions on manufacturer investment, it was often used as a measure of the company's performance or an important indicator of the company's growth. If q-value is greater than 1 , it indicates that the company performs well.

Based on q-theory, Wu Wei (2008) found that the relationship between the company scale and Tobin-q was in accordance with the logarithmic function, after analyzing 300 stocks in the Chinese stock markets. In the corporate governance structure, it was only directors (excluding the independent directors and outside directors) that played a role to reset the company value to the long-term equilibrium level (Tobin-q moving closer to the long-term equilibrium level). After analyzing the Tobin-q, non-tradable shares of listed companies and investment, Li Chunhong, etc. (2003) believed that Tobin-q reflected the company investment value to some extent.

\section{CORRELATION ANALYSIS ON CEO's SALARY AND TOBIN-Q}

\section{A. The q-theory}

Hypothesis: (1) the firm production function or revenue function only depends on capital $\mathrm{Kt}$ and labor $\mathrm{Lt}$, namely $Y_{t}=F\left(K_{t}, L_{t}\right)$ (where, $\mathrm{F}$ is continuously differential concave function); (2) the real price of investment goods is $\mathrm{Pt}$, and the real wage is $\mathrm{Wt}$; (3) the adjustment cost of fixed assets is defined as $C\left(I_{t}, K_{t}\right)$ (where, $\mathrm{I}$ is investment), and it meets:

$$
\frac{\partial C\left(I_{t}, K_{t}\right)}{\partial I_{t}}>0, \quad \frac{\partial^{2} C\left(I_{t}, K_{t}\right)}{\partial I_{t}{ }^{2}}>0
$$

This means the cost function, $C\left(I_{t}, K_{t}\right)$, is the twice continuously differentiable and strictly increasing convex function, so it is optimal choice that adjust gradually in shortterm.

Based on the hypothesis, the company net income in the time- $t$ can be defined as:

$$
R_{t}=F\left(k_{t}, L_{t}\right)-W_{t} L_{t}-P_{t} I_{t}-C\left(I_{t}, K_{t}\right)
$$

At time-t, the company faces the following optimization:

$$
\begin{gathered}
\max V_{t}=\int_{t}^{\infty} R_{t} e^{-r t} d t \\
s, t, \quad \frac{d K_{t}}{d t}=I_{t}-\delta K_{t},(\delta \text {, the depreciation rate }) .
\end{gathered}
$$

So, we can obtain Hamilton equation:

$$
\begin{aligned}
& H_{t}=R_{t}+q_{t} \frac{d K_{t}}{d t} \\
& =F\left(K_{t}, L_{t}\right)-W_{t} L_{t}-P_{t} I_{t}-C\left(I_{t}, K_{t}\right)+q_{t}\left(I_{t}-\delta K_{t}\right)
\end{aligned}
$$

Therefore:

$$
\begin{gathered}
\partial F\left(K_{t}, L_{t}\right) / \partial L_{t}=W_{t} \\
P_{t}+\partial C\left(I_{t}, K_{t}\right) / \partial I_{t}=q_{t} \\
-\partial H / \partial K_{t}=d q_{t} / d t-r_{t} q_{t}
\end{gathered}
$$

Substituting the derivation of (2) into (5), we can get the function:

$$
\begin{aligned}
& \frac{d q_{t}}{d t}=\left(r_{t}+\delta\right) q_{t}-F_{k}^{\prime}\left(K_{t}, L_{t}\right)+C_{k}^{\prime}\left(I_{t}, K_{t}\right) \\
& q_{t}=\int_{t}^{\infty}\left[F_{k}^{\prime}\left(K_{s}, L_{s}\right)-C_{k}^{\prime}\left(I_{s}, K_{s}\right)\right] e^{-\delta(s-t)} d s
\end{aligned}
$$

Supposing that,

$$
C\left(I_{t}, K_{t}\right)=g\left(\frac{d K_{t}}{d t}\right)=g\left(I_{t}-\delta K_{t}\right),
$$

Wherein, $g \geq 0, g^{\prime}(\cdot)>0, g^{\prime \prime}(\cdot)>0$, by formula(4), we can obtain:

$$
g^{\prime}\left(I_{t}-\delta K_{t}\right)=q_{t}-P_{t}
$$

$G(\cdot)$ is defined as the inverse function of $g^{\prime}(\cdot)$, i.e. $G(\cdot)=g^{\prime-1}(\cdot)$, the $G^{\prime}(\cdot)>0, G^{\prime}(0)=0$, so we can get:

$$
I_{t}-\delta K_{t}=G\left(q_{t}-P_{t}\right)
$$

Equation (9) is the core formula of q-theory, and it indicates that the net investment of fixed assets is the strict increasing function about the shadow price of capital qt, the qt greater, and the net investment greater.

If we define:

$$
q_{t}=M E I / r=\left[F_{K}^{\prime}\left(K_{t}, L_{t}\right)-M A C\right] / r
$$

(MAC is the marginal adjustment cost, and MEI is the marginal efficiency of investment), according to Tobin's theory (1969), if qt $>1$, the investment should be increased, and if qt $<$ 1 , the investment should be decreased.

If we define, $q_{t}=V_{t} /\left(P_{t}, K_{t}\right)$, that is the company value at time $t$ divided by the value of fixed assets, which is also known as the "average q". If qt $>1$, the decision of investment can be made, and this is very convenient for the empirical research and investment decisions.

In demonstration analysis, equation (10) was usually used to calculate Tobin-q (Li Chun, 2003; Wu Wei, 2008). 


$$
q=\frac{V_{1}+V_{2}+B}{A}
$$

Where: V1 is the value of tradable shares; V2 is the value of non-tradable shares; $\mathrm{B}$ is the value of liabilities; $\mathrm{A}$ is the value of total assets.

\section{B. Variables and Sample data}

Based on the above analysis, the data included the total market values, total assets, and total liabilities of 122 listed companies in 2011. The sample firms were set up before 2000, and had not mergers and acquisitions or substantial changes, and had a general manager or CEO (professional managers, not part-time directors, supervisors or chairman), and submitted the annual reports before June 30th, 2012. The data also included the annual monetary total income (W) of 122 CEO's in 2011, which represented the remuneration (not including equity incentives). All data were obtained from the database of CMSAR.

We can get the value of Tobin-q of 122 listed companies by (10), which were shown in figure 1 with the CEO's remunerations $(\mathrm{W})$.

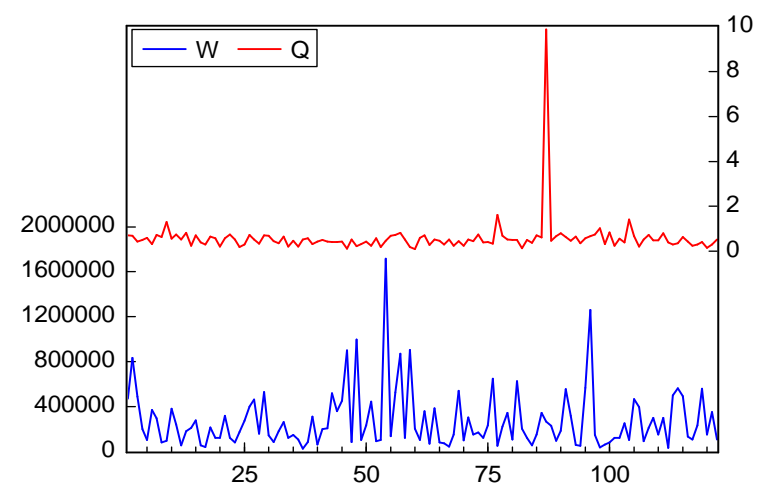

FIGURE 1. THE VALUE OF W AND TOBIN-Q

Note: The left vertical axis is thevalue of $W(\mathrm{RMB})$, and the right coordinate axis is the value of Tobin-q.

\section{The Correlation of $W$ and Tobin- $q$}

In order to demonstrate if the CEO's compensations are associated with the values of the listed companies, we can create the following simple linear equations, (11) and (12), using the real value and logarithm of $\mathrm{W}$ and Tobin-q obtained from figure 1 , for comparing.

$$
\begin{gathered}
L n W_{i}=\alpha_{0}+\alpha_{1} \operatorname{Lnq}_{i}+\varepsilon_{i} \quad i=1,2, \cdots 122 \\
W_{i}=\beta_{0}+\beta_{1} q_{i}+\mu_{i} \quad i=1,2, \cdots 122
\end{gathered}
$$

Regression results are shown in table 1 . We use ordinary

\begin{tabular}{|c|c|c|c|}
\hline \multirow{2}{*}{ Parameter } & \multicolumn{2}{|c|}{ Variables } & \multirow{2}{*}{ Sample } \\
\hline & $W$ & $L n W$ & \\
\hline Constant & $\begin{array}{c}275502.10^{* * * *} \\
(218.50)\end{array}$ & $\begin{array}{l}12.11 * * * \\
(2848.52)\end{array}$ & \multirow{7}{*}{122} \\
\hline$q$ & $\begin{array}{c}-1735.28 \\
(-0.40)\end{array}$ & & \\
\hline Lnq & & $\begin{array}{c}-0.05 * * * \\
(-6.23)\end{array}$ & \\
\hline$R^{2}$ & 0.99 & 0.99 & \\
\hline$A d j-R^{2}$ & 0.99 & 0.99 & \\
\hline$D W$ & 1.89 & 2.13 & \\
\hline$F$ & 0.16 & 38.76 & \\
\hline
\end{tabular}
least squares (OLS), modified with heteroskedasticity.
TABLE I. REGRESSION RESULTS

From the regression results shown in table 1, we know that, as $\mathrm{F}$ statistic is not significant, the equation (12) is misspecified. As the t-test of $q$ is not significant, it is not suitable for using $\mathrm{q}$ to illustrate $\mathrm{W}$. The regression results of (11) are better. The coefficient of Lnq is significantly different from 0 , and the probability that the coefficient equals 0 is less than $1 \%$, which can be indicated from the t-statistic (-6.23)of Lnq. Moreover, the F statistic is also significant for equation (11). Mathematically, we have shown in previous sessions that the coefficient of Lnq represents the elasticity of CEO's pay to q; we can conclude that the salaries of CEO's (W) are related to the value of Tobin-q, and W's elasticity to q will be smaller as the value of $q$ increasing.

\section{CONCLUSIONS}

From our empirical analysis, we show that there is a high correlation between the executive salary and the firm value, and it is effective for the board using incentive compensation to align the interest of CEO, with shareholders.

Nevertheless, it should be noted that the application of Tobin-q in China also has some limitations, including the market conditions that there should not be price deviation between the primary market and second market, and the funds raised by issued shares should be used for industrial investment But in China, due to the new issue premium, many funds raised by issued shares flowed back in the stock market, and this led the stock prices deviate from their intrinsic value, and thus fail to effectively stimulate industrial investment. This will result in the inaccurate Tobin-q, based on the market prices.

At the same time, it should be noted that in the previous analysis, this paper analyzed only one year samples, and explained the relationship between the company executive compensation and the value of each company by using sectional data. For further research, we can analyze this relationship by using the time series data of each company. Meanwhile, future research should also consider the impact of other factors like industry, region, ownership and enterprise scale or type.

\section{ACKNOWLEDGMENT}

Funds: Humanities and Social Science Fund Project of China Education Ministry (10YJC790111), Humanities and 
Social Sciences project of Hubei Provincial Education Department (2011jyty039).

\section{REFERENCES}

[1] Nickell, Stephen J. and Bell, Brian, "The Col-lapse in Demand for the Unskilled and Un-employment Across the OECD," Oxford Review of Economic Policy, vol11(1), pp. 40-62, , Spring, 1995.

[2] Eisenhardt K., "Agency theory: an assessment and review," The Academy of Management Review, Vol. 14(1), pp. 57-74, Jan., 1989.

[3] James P. Walsh and James K. Seward, "On the Efficiency of Internal and External Corporate Control Mechanisms," The Academy of Management Review, vol. 15 (3) , pp.421-458, July, 1990.

[4] Edward J. Zajac and James D. Westphal, "Director Reputation, CEOBoard Power, and the Dynamics of Board Interlocks," Administrative Science Quarterly, Vol. 41(3), pp. 507-529, Sep. 1996.
[5] Tobin, J., “A general equilibrium approach to monetary theory,” Journal of Money, Credit and Banking, Vol.1, pp.15-29, 1969.

[6] Abel, A., "Empirical Investment Equations : An Integrative Framework, 1979. in K.Brunner and A. Meltzer, eds. "On the State of Macroeconomic," Journal of Monetary Economics Supplement, vol.12, pp.39-91, 1980.

[7] Yoshikawa, H., "On the 'q'-Theory of Investment," American Economic Review,vol.70, pp.734-739, 1980.

[8] Hayashi, F., "Tobin' s Marginal and Average q :A Neoclassical Interpretation," Econometrics, vol.50, pp.213-224, 1982.

[9] Wu Wei, "Based on Tobin's q value of the company's corporate governance and Empirical Analysis," Social Sciences, vol.(7), pp. 24-27, 2008.

[10] LI Chun, "Tobin's Q, non-tradable shares of listed companies and investment analysis," Seventh National Youth Science Management $\begin{array}{lll}\text { Science and } & \text { Systems }\end{array}$ 